\title{
Obituary
}

Prof. Max Rubner

$B^{Y}$ the death of Geheimer Obermedizinalrat Prof. Max Rubner on April 27, the world has lost one of the most outstanding workers in the field of general nutrition. Rubner, born on June 2, 1854 , belonged to the older school of workers who were interested in nutrition, for the most part, from its quantitative aspect, but although his greatest contributions to science were made in this field, even to the end he had also a lively interest in the qualitative side. A student in Munich, he became early in his career interested in the problems of metabolism and naturally gravitated to the laboratory of Carl Voit, becoming, after having spent a year in Ludwig's laboratory, one of his assistants and eventually Privatdozent (1883). In 1885 he was appointed to the newly founded chair of hygiene at Marburg as extraordinary professor, becoming ordinarius two years later. In 1891 he was called to Berlin to succeed R. Koch in the chair of hygiene there. This chair he retained until 1909, when he transferred to the chair of physiology in Berlin, vacant by Engelmann's death. This post he held until 1922, when he retired from active professorial work. He was Rector of the University of Berlin in 1910-11.

Rubner was undoubtedly one of the most energetic and stimulating workers in German biological science. In his early days with Voit he confined his attention to metabolic problems. It can be fairly stated that it was he who was mainly responsible for the application of the physical conceptions of Helmholtz and Mayer to biological material. Although he was not the inventor of the bomb calorimeter for the determination of the heats of combustion of foodstuffs, it was his research work in this field which established not only the crude but also the biological calorie values of protein, carbohydrate, and fat, which are accepted as international standards to-day.

Rubner's interest in the energetics of metabolism, begun in Munich, led at Marburg to extraordinarily fruitful research. It was during his Marburg period that he devised his ingenious animal calorimetric work, which enabled him to put forward his law of the specific dynamic action of foodstuffs and to give final and conclusive proof of his fundamental conceptions on the relation of the energy expenditure of an animal to its surface area. This period of his activity is reflected in his most original contribution, "Die Gesetze des Energieverbrauchs" (1902). This is undoubtedly a great but a very difficult book. It used to be said that there was only one man in Europe who could interpret it, and that was not Rubner himself but his friend and former Marburg colleague, Hans Meyer of Vienna. Rubner literally established the energetics of metabolism on a solid and lasting foundation.

Although his view of the work to be carried out by a professor of hygiene would seem at first sight to have been more of the nature of experimental physiology, Rubner did not neglect, particularly after his translation to Berlin, the other aspects of his subject, as his many papers on public health subjects and finally his excellent textbook of hygiene (1907) attest. The range of his interests is simply astonishing, as is also the general high level of the material published.

Undoubtedly the subject nearest Rubner's heart was nutrition in the broadest sense of the termnutrition as it concerned the people, its relation to growth, to general health. In addition to special sections on food in several large handbooks, he published several volumes of his own; for example, "Kraft und Stoff im Haushalt der Natur" (1909) and "Volksernährungsfragen" (1908), as well as numerous papers in the Archiv für Physiologie and other journals.

During the War years, Rubner played an active part in the working out of diets and the determination of the biological food value of various 'food substitutes '. Even after his retirement from his professorial chair, Rubner interested himself actively in the development of the Kaiser-Wilhelm Institut für Arbeitsphysiologie, Berlin (now in Dortmund). $\mathrm{He}$ was a member of many Government committees, and was for many years secretary of the Prussian Academy of Sciences, the Sitzungsberichte of which contain many of his interesting general papers.

E. P. C.

\section{Mr. R. H. AdIE}

Richard Haliburton Adie, of Trinity College, Cambridge, died on May 18, in his sixty-eighth year. To University, County, and Town he was for many years a familiar figure, and in their activities his work and personality were widely respected. It was the privilege of few to see so closely and for so long the development of agricultural education in Great Britain. In the first agricultural course held in Cambridge, commencing in 1891, Adie was a fellow-student of the late T. B. Wood and Cecil Warburton. His first appointment was as an extension lecturer in agriculture in Devon, which he relinquished to return to Cambridge. A small band, with vision and enthusiasm, had created the Cambridge and County Committee for Agricultural Education, and in 1895 he gave for them the first course of lectures in agricultural economics. Adie's initial studies had been principally in chemistry, and on returning to Cambridge he took charge of the chemical laboratory at St. John's College. College teaching in chemistry continued until the outbreak of the War, and great numbers of men look back to the geniality and patience under which they began the study of chemistry in St. John's.

The year 1899 saw the creation of a Department of Agriculture in the University. It was housed in two basement rooms of the University Chemical Laboratory, the head of which, the late G. D. Liveing, was its most valued friend. Resources were meagre, but the faithful service and remark. able versatility of the pioneer teachers laid foundations for the big developments which were to come. 
Adie played an important part here as lecturer in agricultural engineering, surveying, and chemistry, and no less valuably in general development. Happily for the future of agriculture in Cambridge, his interest in civic matters grew rapidly at this time. By 1907 he was a member of the Cambridgeshire County Council, a body on which he served to the end of his life. He was also a member of the Cambridge Borough Council, becoming an alderman in 1914. In these early days, the financial support and the sympathy of the counties for agricultural education was of primary importance, and Adie's constantly growing influence in county administration enabled him to arouse among farmers and landowners a realisation of the part education could play in agricultural progress.

By 1914 the (then) Board of Agriculture scheme for advisory officers had been launched, and Adie became first secretary of the Provincial Council administering it. Throughout the War he was secretary of the Cambridgeshire Agricultural, Committee. The School of Agriculture had to bear a full share of the sudden, heavy burden of reorganisation and pressure from students, brought by the cessation of war in 1918-19. It fell to Adie to lecture in engineering and surveying for both agriculture and forestry and in elementary chemistry and physics. In addition, he was secretary of the Special Board for Agriculture and Forestry, which, in its later form, the Faculty Board of Agriculture and Forestry, he served until his resignation in 1929. The lectures in agricultural engineering he continued to within a few weeks of his death.

Adie impressed his pupils by kindness, patience, and a flair for demonstration. His colleagues recognised in him a master of administrative procedure, a man of great stability, tenacity, and selfpossession. To younger men, including those to whom by degrees he handed over his duties, he gave help, advice, and encouragement unsparingly.

\section{Dr. H. Seidelin}

Dr. Harald Seidelin, who died at Antwerp on April 29, was born at Aarhus (Denmark) in 1878, and studied medicine at the University of Copenhagen. In 1904 he went to Mexico, and became professor of pathology and bacteriology in the University of Yucatan, where his work was mainly concerned with investigations into the cause of yellow fever. He returned to Europe in 1910, and the following year joined the staff of the Liverpool School of Tropical Medicine as scientific secretary to the Yellow Fever Bureau. He took part in expeditions of the School to Yucatan and Jamaica to study yellow fever, vomiting sickness, and other obscure tropical diseases, and in 1912 he described certain minute bodies, found in the erythrocytes of yellow fever cases, which he believed to be the causative agent of yellow fever. He gave them the name, Paraplasma flavigenum, but his view of the parasitic origin of yellow fever was finally refuted in 1914 by Wenyon and Low. The last seventeen years of Dr. Seidelin's life were devoted to the organisation and development of the medical service of the S.A. des Huileries du Congo Belge (Lever Brothers). Under his able and energetic leadership this service rose to a high state of efficiency, and he was honoured by the Belgian Government in 1929 with the decoration of Chevalier de l'Ordre Royal du Lion. Seidelin was a hard worker, a capable administrator, a careful investigator, and a brilliant linguist, speaking fluently half a dozen languages.

Ww regret to announce the following deaths :

Prof. J. W. Gregory, F.R.S., emeritus professor of geology in the University of Glasgow, aged sixty-eight years.

Prof. A. A. von Jaczewski, director of the Phytopathological Institute in Leningrad, on $\mathrm{Feb} .12$.

\section{News and Views}

New Associates of the Royal Astronomical Society

THE following have been elected associates of the Royal Astronomical Society: Prof. Giorgio Abetti, director of the Royal Astrophysical Observatory at Arcetri, Florence, who is known for his observations on the chromosphere and on solar prominences; Prof. R. Emden, professor of physics, Technical High School, Munich, and author of "Gaskugeln" (1907), which consolidated and extended earlier work on the internal constitution of the stars, and has been the foundation of more recent work on this subject; M. Ernest Esclangon, director of the observatories at Paris and Meudon, who in addition to astronomical work has carried out a gravity survey in south-western France; Prof. H. Ludendorff, director of the Potsdam Observa. tory, and in 1920-30 secretary of the Astronomische Gesellschaft, distinguished for his work on stellar spectroscopy; Prof. P. J. van Rhijn, director of the Kapteyn Astronomical Laboratory, Groningen, Holland, author of numerous papers on the proper motions and distribution of the stars.

\section{Franklin Institute Awards}

THe following medals, among others awarded by the Franklin Institute, Philadelphia, were presented on May 18. Franklin Medals to Dr. Ambrose Swasey, of Cleveland, Ohio, for his development of methods and his invention of appliances for making machines, tools, and instruments of the highest precision, of the design and construction of the mountings of many of the world's largest telescopes, and for his scientific vision in the establishment of the Engineering Foundation for the promotion of research and its application in the various fields of engineering; Dr. P. Lenard, of the University of Heidelberg, in recognition of a life's work devoted to fruitful research in physics, which has included the demonstration of cathode rays outside the generating tube and their effects, the discovery of the electronic nature of the emission from surfaces upon which ultra-violet light falls, as well as the basic laws of photoelectricity. Elliott Cresson Medals to Dr. P. W. Bridgman, of the Jefferson Physical Laboratory of Harvard University, Cam.

No. 3268, VoL. 129] 